\title{
Study of Youth Anxiety Levels on No-Mobile Phone (Nomophobia) in Padang City
}

\author{
Dwi Christina Rahayuningrum ${ }^{1}$, AnnisaNovita Sary ${ }^{2}$ \\ ${ }^{1}$ StikesSyedzaSaintika, Padang- Indonesia, $\square$ dwichristina05@gmail.com \\ 2 StikesSyedzaSaintika, Padang- Indonesia, $\bowtie$ annisa.novita1011@gmail.com
}

\begin{abstract}
Smartphones have become a means of communication and information in everyday life. This situation makes a person have a dependency in life on mobile phones. Too often the use of mobile phones will cause Nomophobia to begin with smarthphone addiction, assuming that mobile phone is a very important and inseparable need for life. Currently the problem of Nomophobia has occurred in several countries in the world even in Indonesia, this problem is a psychosocial problem. This study uses an analytical approach with quantitative design. Research was conducted on adolescents of high school in the city of Padang in 2018 with a sample of 147 people. Data was collected through questionnaires. The purpose of this study is to be able to study the level of teen anxiety with mobile phones. This research began in July 2018 at Senior High Schools in Padang City. The results obtained for students' anxiety level is $54.5 \%$ of high school teenagers in Padang City experience moderate anxiety, and $47.6 \%$ of high school teenagers in Padang City experience moderate nomophobia. There is a relationship between the level of anxiety of high school teenagers towards nomophobia in Padang City.
\end{abstract}

Keywords:Smarthphone, nomophobia, anxiety level.

\section{Introduction}

Mobile phones have made changes from simple communication tools to sophisticated communication devices that are often referred to as smartphones (Cheever, et al., 2014). Smartphones have become a means of communication and information in everyday life (Caglar, 2014). Mobile phones are one of the most commonly used communication devices in daily activities (Yildirim, 2014). Backer (2010) states that smartphones function like computers by offering features such as personal digital assistants (PDAs), internet access, email, and Global Positioning System (GPS). Besides that, smartphones also function like cameras, videos, games, social media (paths, Facebook, Twitter, Instagram, etc.), MP3 players, and other features. 
Information and communication technology has become an integral part of life. Smartphones facilitate individuals in the process of communicating and providing a level of mobility that allows smartphone users to be contacted at any time (Lucia, 2014). Smartphone mobility provides benefits and helps people meet their basic needs, but it can also cause several problems related to smartphone use (Yildirim, 2014). Individual relationships with smartphones greatly affect interpersonal behavior and social habits. Communication technology also makes changes in community interaction with the world, perceptions of real interactions and smartphone interaction (Lucia, 2014). The psychological impact of the use of technology on individuals, groups and society is generally associated with changes in behavior and habits before and after the existence of smartphones (King, et al., 2013). This situation makes a person have a dependency in life on mobile phones.

Nomophobia or the abbreviation of no-mobile phone is a condition that cannot be separated from a cell phone (Cheever, et al., 2014). Nomophobia is considered a modern and recent disorder that has been used to describe the discomfort or anxiety caused by not being close to virtual communication devices such as mobile phones (King, et al., 2013). Fear of loneliness makes individuals use smartphones as a means of communication and get information that is too excessive to experience Nomophobia.

The results of research conducted by Bivin (2013) found that nearly $53 \%$ of smartphone users in the UK tend to be anxious when they lose their smartphone, run out of battery, or do not have network coverage. The study also found a new disorder called Nomophobia or an abbreviation of nomobile phone phobia that describes people's fear of mobile phone devices (Cheever et. Al, 2014). Nomophobia is considered a modern and recent disorder that has been used to describe the discomfort or anxiety caused by not being close to virtual communication devices such as cell phones (King, et. Al. 2013).

Nomophobia disorders increase significantly, based on a survey conducted by SecurEnvoy (2012), which is from $53 \%$ from 2008 to $66 \%$, this involved 1000 people as participants. Furthermore, the survey found that Nomophobia was mostly in the category with an age range of $18-24$ years $(77 \%)$ and was followed by respondents aged 25-34 years (68\%). The number of people with Nomophobia in Indonesia experienced a significant increase, in 2013 around $75 \%$ with an age range of 18-24 years (Mahendra, et al., 2013) and in 2014 people with Nomophobia were around $84 \%$ in the span of 19-24 years (Mayangsari, 2014) . Based on their age range, teenagers are known to complain most about Nomophobia (SecurEnvoy, 2012).

Nomophobia has various effects such as experiencing anxiety, loneliness, anxiety, panic, sadness, sweating and trembling when separated or not near the smartphone (Bragazzi\& Puente, 2014; King, 2013). According to Badwilan (2004) smartphone usage has an impact on health, psychological and social aspects. First, the effect of cellphone use on health shows that smartphone use triggers a tendency to hearing problems, cancer, brain tumors. Second, the social effects of smartphone users can interfere with the concentration of ringtones, reduce the quality and quantity of direct (face-toface) communication and trigger misunderstanding in the meaning of messages through indirect communication. Third, the psychological effect of using smartphones comes from misuse of smartphone usage which causes women to bullying others through short messages (sms).

The results of the study on health students also showed that $39.5 \%$ of students received low scores in the exam if they spent more time using mobile phones (Prasad et all, 2017). The results of previous studies also showed that the level of motivation to play teenagers.

\section{Methodology}


This type of research is analytic, with a cross sectional design that is a research design by taking measurements or observations at the same time (one time). The study was carried out at the State High School in Padang City. The population in this study were 4,168 public high school teenagers in the city of Padang. The sample is part of the population that fulfills the inclusion and exclusion criteria totaling 147 people. Inclusion criteria: high school children aged 16-19 years, not physically disabled, and in good health. The study used a questionnaire with interview method.

\section{Results and Discussion}

This research has begun to take place in July 2018, at the research location in several high schools located in Padang City, namely schools located in Koto Tangah Village, Padang Barat Village and Padang Utara Village. The samples obtained until September 2018 were 147 people. The results obtained are as follows:

\subsubsection{Adolescent Anxiety Level}

The frequency distribution of teen anxiety levels can be seen in the following table:

Table 5.1Distribution of Frequency of Adolescent Anxiety Levels

\begin{tabular}{ccc}
\hline Anxiety Level & F & \% \\
\hline Mild Anxiety & 13 & 8,8 \\
Medium Anxiety & 80 & 54,5 \\
Hard Anxiety & 54 & 36,7 \\
Total & 147 & 100 \\
\hline
\end{tabular}

Based on table 5.1 more than half (54.5\%) of adolescents who experience moderate levels of anxiety

Anxiety is a group of conditions that give an important picture of excessive fear, accompanied by behavioral, emotional, and physiological responses. Anxiety is related to the pressure faced by students to achieve high grades when having to part with a mobile phone, fearing that they cannot interact with friends or others. In addition to cognitive aspects, emotional factors also contribute to the reason for anxiety

\subsubsection{Nomophobia}

The nomophobia frequency distribution can be seen in the following table:

Table 5.2Distribution of Frequency of Nomophobia

\begin{tabular}{ccc}
\hline Nomophobia & $\mathbf{f}$ & $\mathbf{\%}$ \\
\hline Mild Nomophobia & 10 & 6,8 \\
Medium Nomophobia & 70 & 47,6 \\
Hard Nomophobia & 67 & 45,6 \\
Total & 147 & 100 \\
\hline
\end{tabular}

Based on table 5.2, less than half (47.6\%) of teenagers experience moderate nomophobia

Smarthphone as a very powerful communication support tool. With Smarthphone, humans can carry out communication and transaction activities easily and quickly. The promises promised by Smarthphone finally make students accustomed and tend to be dependent

Based on table 5.2, less than half (47.6\%) of teenagers experience moderate nomophobia. 
Smarthphone as a very powerful communication support tool. With Smarthphone, humans can carry out communication and transaction activities easily and quickly. The promises promised by Smarthphone finally make students accustomed and tend to be dependent

5.1.3 Adolescent Anxiety Levels Against No-Mobile Phone (Nomophobia) Thenomophobia frequency distribution can be seen in the following table:

Table 5.3Distribution of Frequency of Adolescent Anxiety Levels on No-Mobile Phone (Nomophobia)

\begin{tabular}{|c|c|c|c|c|c|c|c|c|}
\hline \multirow{3}{*}{$\begin{array}{c}\text { Anxiety } \\
\text { Level }\end{array}$} & \multicolumn{6}{|c|}{ nomophobia } & \multirow{3}{*}{$\begin{array}{c}\text { Jumlah } \\
\quad \%\end{array}$} & \multirow[t]{3}{*}{$\mathbf{P}$} \\
\hline & \multicolumn{2}{|c|}{ Mild } & \multicolumn{2}{|c|}{ Medium } & \multicolumn{2}{|c|}{ Hard } & & \\
\hline & $\mathbf{f}$ & $\%$ & $\mathbf{f}$ & $\%$ & $\mathbf{f}$ & $\%$ & & \\
\hline Mild & 6 & 60 & 1 & 10 & 3 & 30 & 100 & \\
\hline Medium & 4 & 5,7 & 64 & 91,4 & 2 & 2,9 & 100 & 0,000 \\
\hline Hard & 3 & 4,5 & 15 & 22,4 & 49 & 73,1 & 100 & \\
\hline Jumlah & 18 & 100 & 99 & 100 & 30 & 100 & 100 & \\
\hline
\end{tabular}

Based on table 5.3, the majority of respondents were $91.4 \%$ of teenagers with anxiety levels were experiencing moderate nomophobia. Based on statistical tests it was found that there was a relationship between the level of adolescent idiosyncrasies on the number of mobile phones (nomophobia)

The anxiety of separating from mobile phones nowadays often happens to students, based on the results of interviews with students it was found that students said they could not part with mobile phones, always wanted to access the internet, connect with social media. Because currently mobile phones are no longer used as mere communication tools, more than that, lat is so important that it cannot be abandoned in every day's activities. Until this dependency continues to increase and has a negative effect on health, because behind it all, there are very large things concerning human psychology or the user will not be aware of this and the danger posed by mobile phone dependence called nomophobia.

\section{Conclusions and Recommendations}

Based on the research conducted on 147 samples, it can be concluded that:

a. More than half more than half (61.2) of adolescents who experience moderate levels of anxiety

b. More than half $(67.3 \%)$ of adolescents experienced moderate nomophobia.

c. Against the relationship between the level of anxiety about No-Mobilephone (Nomophobia) in Padang City.

\section{Suggestion}

1. It is expected that the results of this study can be used as a comparison if further research is conducted on Nomophobia among school-age children

2. It is expected that the School will carry out cross-sectoral collaboration to overcome nomophobia among adolescents so that there will be no worse impacts and can screen schools.

\section{References}

Anindita, Natasha. (2013). Talent BeritaSehat 'Nomophobia'. 
Budiharto. 2008. MetodologiPenelitiankesehatandenganContohBidangIlmuKesehatan Gigi. EGC: Jakarta. Backer, E(2010). "Using Smarthphone and Facebook in A Major Assessment: The Student

Experience".EJournal. Australia : University of Ballarat

Badwilan, R.A. (2004). RahasiaDibalikHandphone. Jakarta :DarulFalah.

Bragazzi, N. L., \& Puente, G. D. (2014). A proposal for including Nomophobia in the new DSM-V.

Psychology Research and Behavior Management, 155-160.

Bivin, J.B1., Mathew, Preeti., et.al. (2013). Nomophobia - Do We Really Need To Worry About?.A cross sectional study on Nomophobia severity among male Under Graduate students of Health Sciences. Vol 1.

ÇaglarKadir, Saglik, Erkan.,Gullluce, Ali Caglar., Kaya,Ufuk., Ozhan,. (2014). Service Quality $\quad$ and Customer Satisfaction Relationship: A Research in 88 Erzurum Ataturk University Refectory.American International Journal of Contemporary Research.

Cheever, Nancy., Rosen, Larry., et.al. (2014). Out of sight is not out of mind: The impact of restricting wireless mobile device use on anxiety levels among low, moderate and high users. Computers in Human Be (Forgays, Hyman, \& Schreiber, 2014)havior, 37. pp. 290-297.

Donnelly, Aisling. ( 2013). Nomophobia-A Modern Age Addiction.

ElidaPrayitno. (2009). Psikologi Abnormal. Padang; FIP UNP

Elmore. (2014). Nomophobia: A Rising Trend in Students

Ibrahim, Ratih. (2015). Metro 360 'MengenalGejalaNomophobia'.

Joshi, Amruta. (2013). Health Effects Of Mobile Phone.

Kurnia, Gadis. (2014). JejaringSosialPemicuNomophobia

King, A.L.S., Valença, A.M., et.al. (2013). Nomophobia: Dependency on virtual environments or social phobia?.Computers in Human Behavior, 29. Pp. 140-144.

Lucia, Anna., Martins, Alexandre., et.al. (2014). "Nomophobia": Impact of Cell Phone Use Interfering with Symptoms and Emotions of Individuals with Panic Disorder Compared with a Control Group. Clinical Practice \& Epidemiology in Mental Health, ,10. pp.28-35.

Mahendra, A.R., Fajariah, I., Ikawidjaja, M., Sudrajad, M \&Putri. N. E. (2013). GangguanKesehatanakibatNomophobiapadaMahasiswaUniversitasAirlangga Surabaya. Surabaya: Airlangga University.

Mayangsari. A. P. (2015). HubunganAntara Self-Esteem denganKetergantunganTeleponGenggam (Nomophobia) padaRemaja. Surabaya: UniversitasAirlangga

Prasad, Patthi.,et al. (2017). Nomophobia: A Cross-sectional Study to Assess Mobile Phone UsageAmong Dental Students.

Rahayuningrum, DC. (2016).

HubunganMotivasiBermaindanDukunganSosialTemanSebayaDenganAdiksi Game Online PadaRemajaSMP N 13 Padang. [Thesis]; UniversitasAndalas. 
Sari, NastriaFitriana. 2016. "PengaruhPenggunaan Smartphone

TerhadapKetergantunganMahasiswaPada Smartphone

(StudipadaMahasiswaJurusanPsikologiUniversitas Muhammadiyah Lampung).

Securenvoy. (2012).66\% of the population suffer from Nomophobia the fear of being without their phone.

Stuart, GW. (2016). Principles and Practice of Psychiatric Nursing. (10 th Ed). Elsevier: Mosby

Widyastuti, Yanidkk. 2009. KesehatanReproduksi. Fitramaya: Yogyakarta.

Yildirim, Caglar. (2014). Exploring the dimensions of Nomophobia: Developing and validating a questionnaire using mixed methods research. Graduate Theses and Dissertations. Lowa State University. 